\title{
The Panic of 1857: Origins, Transmission, and Containment
}

\section{Charles W. Calomiris and Larry Schweikart}

\begin{abstract}
We explain the origins of the Panic of 1857, examine its spread, and compare state banking systems' responses. We describe the decline in western land and railroad investments and the consequent stress on securities brokers and banks in eastern cities, and trace the transmission of the shock to other regions. Bank performance depended not only on regional conditions and links to eastern banks, but on the ability to coordinate behavior. Southern branch banks and coinsuring banks in Ohio and Indiana were particularly successful.
\end{abstract}

C

ontemporaries disagreed on the origins of the Panic of 1857. Hunt's Merchants' Magazine published a partisan attack by Nathan Appleton, a prominent Boston banker, on New York City banks for contracting loans beside an explanation appealing to inexplicable 10year cycles of financial distress. ${ }^{1}$ J. S. Gibbons also criticized New York City banks for contracting loans, but attributed their problem, in part, to deposit withdrawals by New York country banks. ${ }^{2}$ D. Morier Evans blamed excessive speculation by banks and firms. ${ }^{3}$ B. Douglass \& Co. pointed out that the panic had occurred during a prosperous harvest and attributed the "financial revulsion" to "terror inspired by a trifling cause or misapprehension of danger.",4 The Banking Superintendent of New York, James Cook, described the panic as "without apparent reason derived from past experience.",5

Some facts were consistent with the view that the crisis was an unnecessary product of mismanagement or fear. First, the period immediately prior to the panic was one of unusual calm in the markets for commercial bills. From January through August of 1857, interest rates on commercial bills reported in Bankers' Magazine varied well

The Journal of Economic History, Vol. 51, No. 4 (Dec. 1991). (C) The Economic History Association. All rights reserved. ISSN 0022-0507.

The authors are Visiting Associate Professor of Finance, The Wharton School, University of Pennsylvania, Philadelphia, PA 19104, and Associate Professor of History, University of Dayton, Dayton, $\mathrm{OH} 45469$.

We thank Michael Bordo, Louis Cain, Albert Fishlow, Gary Gorton, Jonathan Hughes, Naomi Lamoreaux, Joel Mokyr, Edwin Perkins, Roger Ransom, Hugh Rockoff, Christina Romer, Richard Sutch, Richard Sylla, Peter Temin, Thomas Weiss, Gavin Wright, and two anonymous referees for comments, and James Johnson for excellent assistance.

'Hunt's Merchants' Magazine, 37 (1857), pp. 592-95.

${ }^{2}$ Gibbons, The Banks of New York, p. 2.

${ }^{3}$ Evans, History of the Commercial Crisis.

${ }^{4}$ B. Douglas \& Co., "The Failures in America," reprinted in Evans, History of the Commercial Crisis, pp. 122-34.

5 Cook, "Annual Report," p. 105. 
within the ranges of previous years. ${ }^{6}$ Weekly reports of Thompson's Bank Note and Commercial Reporter indicated little adverse news regarding banks; often it described conditions in money markets from January through August as "easy." Second, the panic was resolved quickly; New York City banks suspended on October 13 and resumed on December 11. Third, few banks failed during the panic, indicating that the underlying disturbance to bank portfolios was small relative to overall bank capital. It would be hard, however, to argue that New York City banks caused the panic. Peter Temin has shown that New York City banks contracted loans only in response to a continuing specie drain. Moreover, suspensions in other eastern cities (Philadelphia, Baltimore, and Washington) preceded New York's suspension by three weeks.

Explanations of the panic encounter difficulties in explaining the timing and location of its onset in the East. George Van Vleck saw the panic as a result of the decline in British capital inflows to the United States, causing a decline of American securities prices, the failure of the Ohio Life Insurance and Trust (Ohio Life), and a run on other banks. ${ }^{7}$ But Temin argued that capital inflows remained large in 1857. Furthermore, Van Vleck failed to provide a convincing story of the timing of the securities market decline, and data on securities prices do not show a general decline in July and August. Finally, Van Vleck did not demonstrate how the securities price declines were linked to the banking panic. Albert Fishlow argued that the panic was a symptom of a recession that began in 1856 , induced by declining investment in railroads that had begun in $1854 .^{8}$ Fishlow has identified an important source of the panic, but he has not explained the timing of the decline in 1857 or the links between railroad securities and banks. Temin conjectured that the panic may have resulted from fears of a repetition of the Panic of 1837 in response to a moderate rise in British interest rates (which he argued caused the Panic of 1837). ${ }^{9}$ The problem with this explanation is that the tightness in British markets peaked in the spring of 1857. From April to August 1857, the Bank of England accumulated gold, while its discount rate fell from 6.5 percent to 5.5 percent. $^{10}$

Authors have assigned varying importance to the failure on August 24 of Ohio Life, an Ohio-based bank with large mortgage holdings, which maintained an office in New York and acted as an intermediary for other Ohio banks investing in eastern financial markets. This was the first major financial institution to experience troubles just prior to the panic,

\footnotetext{
${ }^{6}$ Temin, "The Panic of 1857," pp. 1-12.

${ }^{7}$ Van Vleck, The Panic of 1857.

${ }^{8}$ Fishlow, American Railroads, pp. 100-16.

9 Temin, "The Panic of 1857," and The Jacksonian Economy.

10 Jevons, Investigations, appended diagram I; and Hawtrey, A Century of Bank Rate, p. 281.
} 
and some viewed its demise as a propagator of financial unrest. ${ }^{11}$ But its influence on other banks remains doubtful. First, its failure was known at the time to have been caused by inappropriate (and possibly fraudulent) activities by its management and thus might have had a trivial effect on the perceived risk of other banks' liabilities. Second, its demise preceded by a month the earliest suspensions of banks elsewhere. Finally, banks most directly linked to Ohio Life-correspondent banks in Ohio-were reimbursed at the time of the bank's failure with no loss. Only one bank failed in Ohio during the panic; the others avoided suspending convertibility by credibly coinsuring one another against runs.

The following questions remain about the origins of the panic. What caused banks in eastern cities to suspend convertibility? How could a disturbance with small consequences for banks ex post (one that resulted in few bank failures) cause nearly universal financial disruption and suspension of convertibility? What caused Ohio Life to fail, and how was its failure linked to the general suspension?

Recently, economists have developed models capable of answering the second question. Charles Calomiris and Gary Gorton reviewed these models and argued that during the National Banking Era panics occurred when depositors realized that an important adverse shock had occurred but did not know the precise extent or incidence of the shock among banks. ${ }^{12}$ Disturbances that instigate panics need not be large relative to aggregate bank capital and need not be expected to result in large numbers of bank liquidations. Periods prior to panics involved unusually bad news about bank assets, including stock price declines, commodity price declines, and increased commercial failures.

Similarly, our explanation for the origin of the Panic of 1857 revolves around the financing of western railroad and land speculation in eastern financial markets. The proximate cause of the panic was the bankruptcy of securities brokers who borrowed from eastern banks to finance their dealings in the stock and bond markets. To understand the panic's origins, one must begin with the economic and political history of the speculative boom and bust in investments in the West during the 1850s.

The function of securities markets changed drastically in the United States in the decade prior to the panic. In addition to state and federal bond issues, investors traded large amounts of securities issued by private companies. These securities consisted mainly of railroad bonds and stocks, and to a lesser extent bank stock, miscellaneous corporate securities, and warrants to western lands. Substantial investment in new roads, financed by a booming market for speculative railroad securities

11 Gibbons, The Banks of New York; and Speigelman, "The Failure of the Ohio Life."

12 Calomiris and Gorton, "The Origins of Banking Panics." 
in the East, characterized the early $1850 \mathrm{~s} .{ }^{13}$ Different railroads' earnings followed different paths as the course of American development changed over time. By the mid-1850s railroads could be grouped usefully into three categories: eastern roads that served established routes; older western roads built mainly to serve local distribution needs; and newer western roads, sometimes financed through special land grants to serve as trunk lines connecting older areas of settlement and eastern markets with new areas of settlement. As early as 1854, older locally oriented roads in the West found their earnings falling and their opportunities shrinking, as a result of competition from the new trunk lines. These new lines, with their aggressive land-purchasing policies and far-reaching plans for transcontinental expansion, provided the principal speculative opportunities for railroad investors of the $1850 \mathrm{~s}$. Their fortunes depended on a continuing inflow of settlers and the growth of commerce on the frontier, which required confidence in the viability of expansion westward.

In the spring of 1857 confidence abounded. The Cincinnati Enquirer reported "railroad fever" associated with the completion of the Southern Illinois Railroad through Ohio, especially the Cincinnati-St. Louis link. ${ }^{14}$ According to Allen Nevins, a "fever of speculation in Kansas lands was raging, men selling homes, giving up well paid positions, and even borrowing money at ten percent to purchase farms." Newspapers published along travel routes to Kansas in early 1857 described "a veritable torrent of humanity." The lure of Kansas lands led some to expect Kansas to "increase by seventy thousand people that year." ${ }^{15}$ In April settlers arrived at the rate of 1,000 per day.

The link between immigrant traffic and expectations of railroad profitability is visible in the responses to this great influx. As passengers to Kansas increased, the roads lowered rates for through traffic, indicating expectations of a lasting increase in the volume of business (and perhaps the railroads' desire to encourage immigration to stimulate development). They advertised rate reductions of up to 25 percent. Entrepreneurs laid ambitious plans for new railroads. For example, the Leavenworth Herald reported on May 9, 1857, plans to build a railroad to connect with the Hannibal \& St. Joseph Railroad. Entrepreneurs of these projected railroads included important politicians such as Senator Bigler of Pennsylvania, who had a business partner in Fort Scott, Kansas. Bigler's partner had invested in extensive railroad construction, "for he thought [Fort Scott] would become the principal railway center of southwestern Missouri and northwestern Arkansas. ..." Town lots passed through "a dozen hands within sixty days" as speculators looked to a continual influx of settlers and to expanded rail

${ }^{13}$ Fishlow, American Railroads.

${ }^{14}$ Cincinnati Enquirer, Apr. 16, 1857.

${ }^{15}$ Nevins, The Ordeal of the Union, p. 156. 
links. Newly appointed territorial Governor Robert Walker, arriving in Kansas in May, quickly found himself in opposition to the speculators who grabbed the best land, "especially along projected railroad routes." 16

By late summer that optimism was shattered, the value of western land fell and the speculative railroad securities fell with it. Table 1 provides data on various securities for selected dates surrounding the panic and reveals important differences in price movements across different types of securities. Prices were rising or flat from the beginning of 1857 until March, and an upward trend is particularly pronounced for three of the four trunk-line stocks for which data exist for early 1857 and for Ohio Life. Prices remained flat or fell for these stocks from March to the end of May. By late July a substantial depreciation in trunk-line stocks occurred, while other securities' prices remained constant or fell slightly. From July to early September, trunk-line securities, Kansas land warrants, and stock in Ohio Life fell dramatically (Ohio Life suspended on August 24). Meanwhile, the values of other securities show little or no change. The free fall in trunk-line stocks continued up to September 23 with little or no effect on other securities prices. During the onset of the liquidity crisis in early October (after general bank suspension in Philadelphia, Baltimore, and Washington, and before suspension in New York), the prices of New York state bonds and eastern railroad stocks declined along with trunk-line stocks. After October 21, recovery began, and by the end of the year (by which time New York banks had resumed convertibility) securities prices were roughly at their September 2 levels. Data from the beginning and end of 1859 show that trunk-line stocks continued on a downward trend after the panic had passed, while other securities followed an upward or flat trend.

The decline in speculative railroads' earnings and prospects forced several companies into default, including the Illinois Central, the Erie \& Pittsburgh, the Fort Wayne \& Chicago, and the Reading lines. Several thinly capitalized railroad companies-including the Delaware, the Lackawanna \& Western, and the Fond du Lac-went bankrupt.

Additional evidence supports the view that mid-1857 represented a turning point in expectations about the profitability of westward expansion. According to Paul Gates, the first Kansas public lands had been put up for sale in 1856 and early 1857, and "for the most part settler-claimants secured the lands" at an average of $\$ 1.83$ an acre, or approximately 83 cents above that which the settlers who had military warrants had paid. ${ }^{17}$ The rapid decline in Kansas land values in 1857 brought foreclosure on mortgaged land and general commercial distress.

${ }^{16}$ Crawford, Bigler Papers, cited in Nevins, The Ordeal of the Union, p. 158.

${ }^{17}$ Gates, "Land and Credit Problems," pp. 47, 49. 


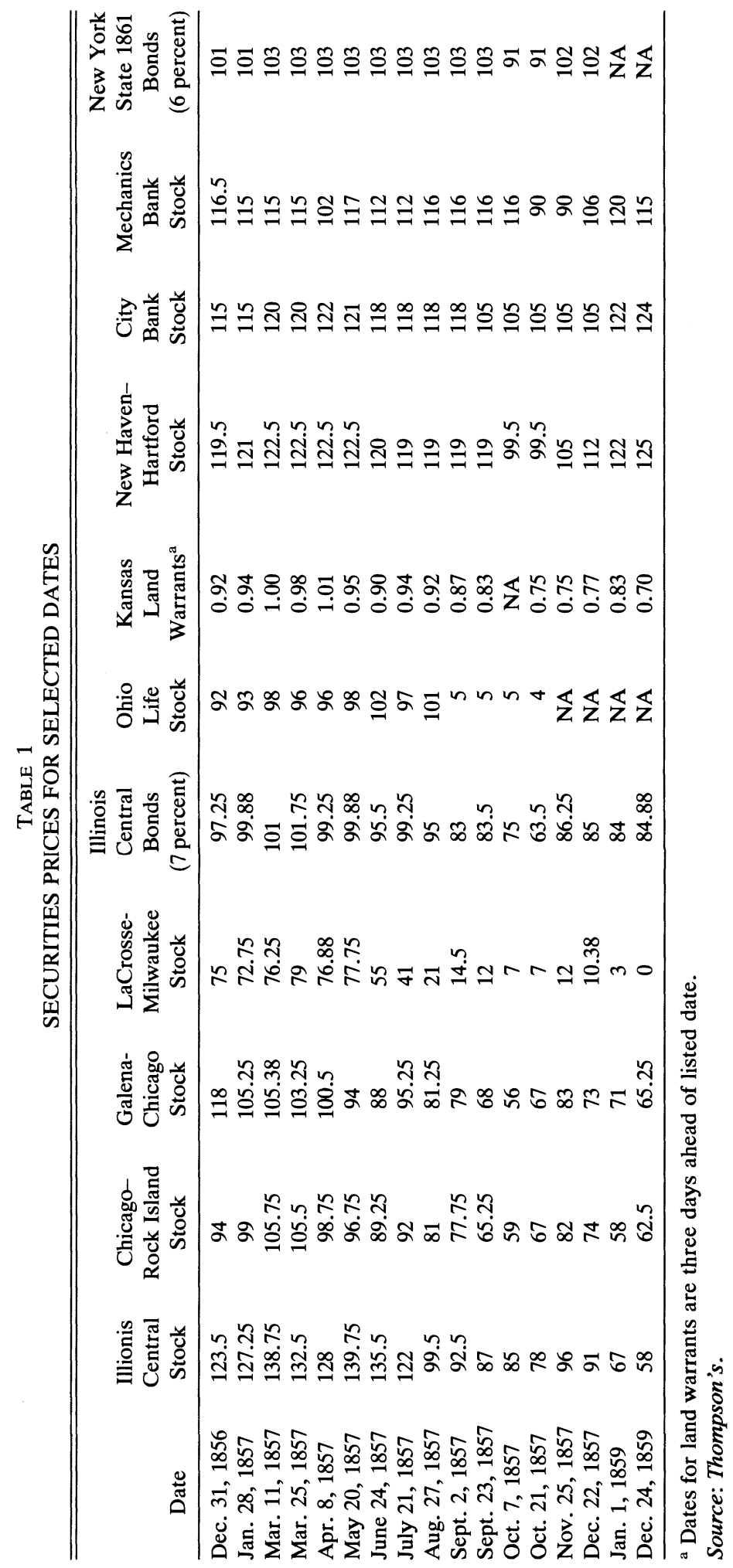


Of the 102 mortgages in Osage County, 45 met with foreclosure from 1858 to 1860 . Of the 246 mortgages in Anderson County, 81 were foreclosed between 1857 and 1861. In Lyon County, 54 of 366 mortgages were foreclosed, and some predicted that as many as two-thirds of the mortgages would end up in foreclosure. ${ }^{18}$ Data on commercial failure rates and losses by creditors of failed firms (Table 2) show that agricultural areas in the Northwest were particularly hard-hit during the panic compared to states in the South or East, with the exception of a few eastern states (especially New York) with close ties to the Northwest.

Persistent declines in western land values and commercial distress in the Northwest coincided with a rapid reversal in the rate of immigration to the West. Fishlow attributed falling western land values and depreciation of western railroad securities after 1857 to declining immigration. The decline in immigration from the East is impressive. "For six major East-West arteries traversing Ohio the number of through passengers declined from 581,000 in 1857-58 to 367,000 in $1859-60 . .$. The difference between western and eastern through passengers on lines entering Chicago from the east, a measure of net migration, declined from an estimated 108,000 passengers in 1856 to a mere 10,000 in $1860 ., 19$ Stephen Salsbury provided annual data on the total number of through passengers (in both directions) carried by the Western Railroad, which shows a similar pattern. The total number peaks in 1856 at 63,246 , falls to 47,637 in 1858 , and declines to 41,674 in $1860 .^{20}$

Thus the asset declines that preceded the panic were confined to a special class of investments in the West and did not reflect a general rise in securities risk or a contraction of foreign credit. Moreover, these asset declines occurred quickly and were concentrated in mid-1857, with an acceleration of decline from August through mid-September.

What caused the rapid reversal in the perceived profitability of westward expansion? Recent work by James Huston has stressed that the Panic of 1857 coincided with a severe agricultural decline in the Northwest that other regions did not share. ${ }^{21}$ Huston suggested that the declining international demand for grain in the aftermath of the Crimean War and the increasing international demand for cotton can explain both the onset of the panic and the regional differences in average growth during this period. Huston contended the fall in wheat prices in August and September 1857 represented the inevitable decline of foreign demand after the Crimean War. This seems unlikely for several reasons. First, the effect of the war's ending should have been reflected in wheat price declines as early as late 1856 . Indeed, wheat prices fell precipi-

\footnotetext{
${ }^{18}$ Ibid., p. 54.

${ }^{19}$ Fishlow, American Railroads, pp. 202-3.

${ }^{20}$ Salsbury, The State, The Investor, and the Railroad, p. 308.

${ }^{21}$ Huston, "Western Grains," and The Panic of 1857.
} 
TABLE 2

COMMERCIAL FAILURES, JANUARY 1857-MARCH 1858

\begin{tabular}{|c|c|c|c|}
\hline Area & $\begin{array}{l}\text { Percentage of } \\
\text { Businesses } \\
\text { Failing }\end{array}$ & $\begin{array}{l}\text { Average Loss } \\
\text { Rate on } \\
\text { Failures }^{\mathrm{a}}\end{array}$ & $\begin{array}{l}\text { Estimated } \\
\text { Creditors' } \\
\text { Loss Rate }\end{array}$ \\
\hline \multicolumn{4}{|l|}{ NORTHEAST } \\
\hline Connecticut & 1.68 & 0.58 & 0.9744 \\
\hline Maine & 1.27 & 0.53 & 0.6731 \\
\hline Maryland (outside Baltimore) & 1.11 & 0.76 & 0.8436 \\
\hline Massachusetts (outside Boston) & 1.57 & 0.51 & 0.8007 \\
\hline New Hampshire & 1.97 & 0.48 & 0.9456 \\
\hline New Jersey & 2.46 & 0.56 & 1.3776 \\
\hline New York (outside New York City) & 4.09 & 0.62 & 2.5358 \\
\hline Pennsylvania (outside Philadelphia) & 2.08 & 0.73 & 1.5184 \\
\hline Rhode Island & 1.85 & 0.67 & 1.2395 \\
\hline Vermont & 2.28 & 0.50 & 1.1400 \\
\hline Philadelphia & 4.40 & 0.74 & 3.256 \\
\hline New York City & 6.15 & 0.65 & 4.000 \\
\hline Baltimore & 3.38 & 0.74 & 2.501 \\
\hline $\begin{array}{l}\text { Boston } \\
\text { NORTHWEST }\end{array}$ & 5.61 & 0.55 & 3.086 \\
\hline Illinois & 2.80 & 0.62 & 1.7360 \\
\hline Iowa & 5.63 & 0.64 & 3.6052 \\
\hline Indiana & 2.51 & 0.66 & 1.6566 \\
\hline Michigan & 3.80 & 0.76 & 2.8880 \\
\hline Ohio & 2.54 & 0.68 & 1.7272 \\
\hline Wisconsin & 4.52 & 0.51 & 2.3052 \\
\hline $\begin{array}{l}\text { Territories } \\
\text { BORDER STATES }\end{array}$ & 2.57 & 0.80 & 2.0560 \\
\hline Kentucky & 1.46 & 0.75 & 1.0950 \\
\hline Missouri & 1.37 & 0.68 & 0.9316 \\
\hline $\begin{array}{l}\text { Tennessee } \\
\text { south }\end{array}$ & 1.37 & 0.59 & 0.8083 \\
\hline Arkansas & 1.51 & 0.55 & 0.8305 \\
\hline Florida & 0.88 & 0.54 & 0.4752 \\
\hline Georgia & 1.01 & 0.78 & 0.7878 \\
\hline Louisiana & 1.94 & 0.63 & 1.2222 \\
\hline Mississippi & 0.58 & 0.63 & 0.3654 \\
\hline North Carolina & 2.08 & 0.70 & 1.4560 \\
\hline South Carolina & 1.96 & 0.62 & 1.2152 \\
\hline Texas & 0.50 & 0.72 & 0.3600 \\
\hline Virginia & 1.32 & 0.61 & 0.8052 \\
\hline
\end{tabular}

a Figures include "frauds" as well as other failures.

b This is estimated as the product of the preceding two columns.

Source: The American Commercial Agency, "Statement of Failures for 1857," in Evans, The History of the Commercial Crisis, pp. 136-37.

tously beginning October 1856 (Table 3) but rebounded in July and August, reaching levels comparable to, or exceeding, those of July and August 1856. Only in September did prices begin to fall rapidly. Second, widespread reports throughout the financial press of a bumper wheat crop in 1857 provide an alternative explanation for the early decline in wheat prices of July and August. The seasonal pattern in wheat prices for the years 1841 to 1860 indicates that prices typically rose from 


\begin{tabular}{|c|c|c|c|}
\hline & \multirow{2}{*}{$\begin{array}{c}\text { Chicago }^{\mathrm{a}} \\
\text { cents/bushel }\end{array}$} & \multicolumn{2}{|c|}{$\begin{array}{c}\text { London }^{\mathrm{b}} \\
\text { per Imperial Quarter }\end{array}$} \\
\hline & & s. & d. \\
\hline \multicolumn{4}{|l|}{1856} \\
\hline January & 132 & 76 & 6 \\
\hline February & 115 & 72 & 6 \\
\hline March & 108 & 68 & 11 \\
\hline April & 116 & 68 & 8 \\
\hline May & 110 & 68 & 0 \\
\hline June & 103 & 69 & 6 \\
\hline July & 104 & 76 & 1 \\
\hline August & 104 & 72 & 10 \\
\hline September & 100 & 67 & 10 \\
\hline October & 90 & 65 & 5 \\
\hline November & 77 & 64 & 1 \\
\hline December & 81 & 60 & 3 \\
\hline \multicolumn{4}{|l|}{1857} \\
\hline January & 88 & 58 & 7 \\
\hline February & 90 & 56 & 0 \\
\hline March & 88 & 55 & 6 \\
\hline April & 100 & 53 & 8 \\
\hline May & 114 & 56 & 7 \\
\hline June & 124 & 60 & 1 \\
\hline July & 120 & 63 & 4 \\
\hline August & 103 & 59 & 6 \\
\hline September & 85 & 57 & 0 \\
\hline October & 73 & 55 & 5 \\
\hline November & 61 & 51 & 3 \\
\hline December & 55 & 48 & 7 \\
\hline
\end{tabular}

a The average of the monthly high and low.

b The average of weekly prices.

Sources: Chicago prices are from Boyle, Chicago Wheat Prices, p. 69. London wheat prices are from Statistical Abstract for the United Kingdom, p. 100, which was kindly provided to the authors by Jonathan Hughes.

November to May, and often peaked in May and June. In years of bountiful harvests, prices fell precipitously from July to September, while in years of small harvests, prices may have remained flat or even rose over this period. For example, from June to August of 1854, 1859, and 1860, wheat prices fell 34,37 , and 23 percent, respectively, compared to a 17 percent decline from June to August 1857. The average seasonal decline from June to August for 1841-1860 was 12 percent. Third, a comparison of British and American price changes (Table 3) shows that reduced foreign demand could not have explained the fall in prices in the summer of 1857. British prices fell very little from August to October 1857. Indeed, this price decline is less than the fall in the wheat price from August to October 1856, or from October 1856 to January 1857. This is consistent with viewing news of the Crimean War and foreign-demand contraction as having its effect much earlier than the panic, and seeing the primary impetus for the U.S. price fall of July 
and August as a response to the bumper crop. The continuing U.S. price declines during and after the panic reflected the liquidity crunch of western farmers. Declining national income during and after the panic reduced demand at a time when farmers were forced to increase sales. In the face of falling land values and the farm debt crisis, farmers must have been willing to liquidate their assets, including grain, at reduced prices.

If the end of the Crimean War did not cause the western land and railroad bust, what did? The answer may lie in the political struggle between "free soil" and slavery in the territories. Beginning with the Dred Scott decision of March 6-7, 1857, the prospects of free-soil interests deteriorated, and uncertainty about the ultimate status of the territories grew. This reduced the territories' attractiveness to new immigrants, especially from the populous North, and reduced the probability of the establishment of further settlements west of the territories, or of government involvement in a transcontinental railroad through Kansas. Such an explanation is difficult to prove, but the coincidence between political news and securities' price movements is suggestive. The salient political news of 1857 included the Dred Scott decision of March 6-7 (which declared the Missouri Compromise unconstitutional); a defeat for pro-slavers on April 8 in the St. Louis mayoral election, which led observers to expect the loss of a Senate seat by pro-slavers; the June election of a constitutional convention for Kansas, rigged in advance by the minority pro-slave group; and the anticipation of a legislative election in October, again rigged by proslavers, which was later overturned by the territorial governor. By July Kansas was gripped by political uncertainties that dampened immigration, land speculation, and prospects for railroad expansion. While it is difficult to match political events to securities' price movements convincingly, we note that Kansas land warrant and western railroad securities' prices declined slightly just after the Dred Scott decision in early March, then recovered at the time of the April 8 election of a free-soiler as mayor of St. Louis, declined again until the June election, and declined drastically in August and September. These movements are consistent with our view that political news about the future of the territories called the tune in the land and railroad-securities markets. ${ }^{22}$

\section{LINKING THE LAND AND RAILROAD BUST TO THE BANKING SYSTEM}

Some historians have assumed a causal link between the collapse of Ohio Life, with its powerful New York office, and the general suspen-

\footnotetext{
${ }^{22}$ Some of the most useful reviews of the political struggle between the North and South over Kansas include Cashin, A Family Venture; Fehrenbacher, Slavery, Law and Politics; Nevins, The Ordeal of the Union; Potter, The Impending Crisis; Ransom, Conflict and Compromise; and Wright, Political Economy.
} 
sion of New York City banks. The early timing of the Ohio Life failure seemed to link it to subsequent suspensions through some form of irrational contagion. But Ohio Life had few characteristics of a commercial bank, its collapse was attributed to special circumstancesmismanagement, or possibly fraud-at the time of its failure, and other banks did not suffer from its demise. Its failure predated by one-to-two months suspensions of other banks. Nevertheless, the early failure of Ohio Life is instructive because it illustrates the connection between the securities market decline and the fortunes of intermediaries.

Ohio Life, which had struggled against heavy bank taxes in the 1850s, had nevertheless reported profits of up to 8 percent in the years preceding the panic. Its assets consisted mainly of securities and loans to railroads. Gripped by "railroad fever" that swept the state, Ohio Life had a special connection to the Cincinnati, Hamilton, and Dayton Railroad whose dividends were payable at Ohio Life. Other railroads likely enjoyed a similar status. To facilitate involvement in the securities market, Ohio Life had opened a New York office, under the direction of Edward Ludlow. ${ }^{23}$

Ludlow's activities immediately prior to the bank's collapse remain murky, but their consequences for Ohio Life's asset portfolio are clear. Ludlow had loaned an amount equal to the company's capital- $\$ 2$ million - to various railroads, including $\$ 500,000$ to the Cleveland \& Pittsburgh. ${ }^{24}$ The report of the receiver of the bank shows the bank holding securities with a nominal par value in excess of $\$ 1$ million. ${ }^{25}$ Thus of its roughly $\$ 4.8$ million in assets, the bank invested $\$ 3$ million in the railroad industry. After the suspension of the bank, the president of Ohio Life, Charles Stetson, immediately launched an investigation. $\mathrm{He}$ apparently did not know what Ludlow had done, indicating Ludlow acted on his own authority. ${ }^{26}$ It remains unclear the extent to which Ludlow's actions were contrary to bank policy, the extent to which they involved fraud, and whether Ludlow simply made risky loans and investments on behalf of the bank, or whether he "borrowed" funds for his own purposes. Nevertheless, given Ohio Life's immediate western railroad connections, and that at least one-fourth of its capital was tied up in a single faltering western road (the Cleveland \& Pittsburgh stock fell from 39 cents a share in July to 20 cents a share in August before the failure of Ohio Life, and later dropped to 15 cents a share), it is understandable that of all the banks in the country Ohio Life would be first to fail. Its fate reflected an underlying problem in the railroad and

\footnotetext{
${ }^{23}$ Haeger, The Investment Frontier, pp. 43-59, 143-144. Actually, a group of easterners owned both Ohio Life and the New York Life and Trust, so it was hardly a case of westerners' branching in the east.

${ }^{24}$ Cincinnati Enquirer, Aug. 28, 1857.

${ }^{25}$ U.S. House of Representatives, "Synopsis of the Report," pp. 206-7.

${ }^{26}$ Cincinnati Enquirer, Aug. 25, 1857.
} 
TABLE 4

MODAL BANK NOTE DISCOUNT RATES IN NEW YORK CITY IN 1857

\begin{tabular}{lccccc}
\hline \hline & Alabama & Georgia & Virginia & New York & Ohio \\
\hline July 29 & $1.5^{\mathrm{a}}$ & 1 & 1 & $3 / 8$ & 1.25 \\
September 16 & 3 & 2.5 & 2.5 & $3 / 8$ & 4 \\
October 7 & 10 & 10 & 10 & 1 & 8 \\
November 4 & 7 & 7 & 15 & - & 6 \\
November 18 & 6 & 6 & 8 & 0.5 & 5 \\
November 25 & 6 & 5 & 6 & $3 / 8$ & 3 \\
December 10 & 3 & 5 & 6 & $3 / 8$ & 2.5 \\
December 22 & 3 & 4 & $6 / 8$ & 2.5 \\
\hline
\end{tabular}

a New entrants were quoted at 5 percent and are excluded.

b Transactions limited by Clearing House policy.

Source: Thompson's.

land markets in the West, to which it was known to be especially sensitive. This explains why its failure did not precipitate a general run on banks in New York, Ohio, or elsewhere.

\section{THE RAILROAD SECURITIES DECLINE AND THE EASTERN BANKS}

Interest rates rose in New York from June through August 1857. Still, markets remained calm. Discount rates on bank notes of distant states trading in New York and Philadelphia remained unchanged until late August and rose slightly after the collapse of Ohio Life (Table 4). New York bank stock remained firm until late September. The central puzzle of the panic is the links among the early securities markets' decline, the later decline in bank note prices and bank stocks, and the eventual suspension of convertibility. Why should a region-specific shock to western land and railroads cause a nationwide suspension originating in the East, and why the protracted delay in the reaction of bank note discount rates, bank stock prices, and bank suspension to the JulySeptember decline in land and railroad securities?

In our view, the adverse consequences of the initial "shock" were viewed as small (relative to aggregate bank capital) and were likely confined to only a few banks. Uncertainty about which banks ultimately might fail (given asymmetric information between banks and their depositors) led initially to relatively minor concerns over banks in eastern financial markets, and there was not a large perceived risk of general suspension, even at the time of the suspensions of late September in Philadelphia, Baltimore, and Washington.

Three destabilizing elements combined to transform the securities collapse into a banking panic. First, the initial increase in bank risk prompted some noteholders and depositors in New York state to convert their bank debt into specie. New York's free banks met this demand through sales of bonds in New York, which helped to depress bond prices further. 
Second, New York banks outside New York City converted their notes into specie mainly through their city correspondents. A regulation of June 1857 regulated city banks' trading in country notes, restricted the discount rate which city banks could charge, and limited the amount of notes that could be returned to peripheral banks without sufficient notice. This regulation, along with rising bank risk, caused a flood of peripheral banks' notes into the city for redemption. This added to the drain of specie from New York City to its correspondents in other eastern financial centers.

Third, as New York City banks came to doubt the solvency of some prominent securities dealers, and as city banks' gold reserves fell in response to the accelerating demand for redemption of peripheral banks' notes, the city banks refused to rollover the debt of the brokers. This forced brokers to sell their bond holdings at rock bottom prices and forced many into bankruptcy. As these bankruptcies mounted, and as securities prices continued to fall, the solvency of New York City banks-whose loans to brokers and dealers often were backed by bonds-came into question. This was the proximate cause of the run on the city banks in mid-October. Thus the declining fortunes of western railroads and declines in western land values, along with a concentration of asset risk and reserve drain in New York City banks, ultimately explain the origins of the panic.

Evidence to support this account comes from securities and bank note prices, flows of funds into and out of the city banks, and the timing of broker failures and bank suspension. By the first week of September, discount rates on bank notes trading in New York City doubled for many banks, but they remained low. They rose from 1 to 2 percent on Ohio banks, and from $1 / 8$ to $1 / 4$ percent on New England banks. Discount rates on Pennsylvania and Maryland banks, and banks in the South, remained unchanged. ${ }^{27}$ Within the next week, despite a few significant failures by banks and brokers, New York City's banks on the whole "remained unshaken" as "little or no panic had seized depositors or noteholders." 28 On September 12 it was learned that the Central America, a ship carrying $\$ 1.5$ million in gold from California, had sunk en route to New York, but this had little effect on prices.

In the succeeding two weeks, however, with the suspension of banks in Philadelphia, discount rates in New York City rose to levels substantially above normal for banks in every state, indicating an increased fear of possible nationwide suspension. Still, discount rates remained low for most states through the third week of September: 1/4 percent for New England, 3/8 percent for New York banks outside of New York City, 3 percent for most of the South, and 4 percent for Ohio. Interior

${ }^{27}$ Thompson's, 1857, various issues.

${ }^{28}$ Cook, “Annual Report,"' p. 112. 
states generally had higher discount rates, but 10 percent was the maximum observed for any state. ${ }^{29}$

During September increased risk coincided with conversions of bank debt into specie, but these conversions in New York were not sudden and would not be described accurately as a run. For New York's interior banks there were substantial note redemptions. These took place mainly in New York City, were precipitated partly by a regulatory peculiarity of New York's banking system, and were not associated with substantial default risk. The discounts on interior New York bank notes (except for banks in receivership) never exceeded 1 percent, even after suspension of convertibility in October. But even this small discount justified a large amount of note conversions in the city. Each New York bank was required by law to assign a bank as its agent in New York City (or Albany). The agent was required to maintain convertibility of the bank's notes at no greater than a $1 / 4$ percent discount. City bank agents made markets in interior banks' notes, but were not allowed to return notes to their source without some notice. During normal times market discounts were typically $1 / 8$ or $1 / 4$ percent, so few notes flowed to the city, and they could be returned roughly as quickly as they arrived. When perceived risk rose in September and October, even though only slightly, it justified large flows of notes to the city. Since all New York state banks had to maintain conversion there, it was easy for note arbitragers to bring all interior banks' notes to the city for redemption (rather than carry each note to its home office) and make a profit on the slight difference between the legally required discount rate and the market rate. Because regulation limited the amount that any agent could present for redemption, city banks accumulated large amounts of interior bank notes.

New York City banks did require interior banks to redeem their notes, insofar as they could, but redemptions by peripheral banks took the form of checks on other New York City banks, not specie, and therefore, did not eliminate the specie drain on the city banks. Interior free banks sold their bonds, which had been deposited with the state government as backing for their notes, and used the proceeds (which took the form of checks on city banks) to redeem their notes from their city agents. As the crisis wore on, government regulations on note clearing operated as a destabilizing mechanism for propagating initial uncertainty by draining specie from the country's main banking reservoir, the New York City banks. It also contributed to the declining value of bonds through the increased supply of bonds sold by interior banks to redeem notes. This further exacerbated the risk of brokers whose assets were mainly in the form of securities.

After September 25-when the Bank of Pennsylvania failed, and

${ }^{29}$ Thompson's, 1857, various issues. 
other Philadelphia banks suspended-specie outflows from New York City banks to redeem interior notes increased. From September 26 to 30 more than $\$ 500,000$ in notes were redeemed; between October 1 and 13 some $\$ 2$ million in interior notes were redeemed. At the time of suspension of convertibility in New York City (October 13), banks there held some $\$ 7$ million in interior bank notes. ${ }^{30}$

It is unclear how important New York's note redemption law was in causing the panic. Earlier suspensions in other eastern cities argue against viewing the regulation as an essential cause of suspension. Nevertheless, note redemptions by city banks were a substantial source of reserve outflow in the crucial weeks prior to the panic. City banks struggled to maintain their reserves in the face of a persistent demand for specie and were forced to contract loans. Contraction in city banks' loans and deposits was substantial from August 22 to October 10, particularly as this was normally the season for expansion. Loans fell from $\$ 120$ million to $\$ 102$ million, and deposits fell from $\$ 89$ million to $\$ 63$ million, while specie reserves increased slightly from $\$ 10.9$ million to $\$ 11.5$ million. ${ }^{31}$

Many city banks' borrowers clamored for assistance. Brokerage houses were particularly needy, but also especially risky, borrowers. It was clear that failure to rollover large amounts of loans coming due on October 4 to these borrowers could have adverse consequences in all financial markets-through its effect on securities prices and consequent effects on call-loan collateral-and so the Clearing House banks of New York City met on September 29 to reassure everyone that such credit would be forthcoming.

This promise, however, was not kept due to a combination of the city banks' inability to do so (due to the persistent gold outflow) and their unwillingness to do so (given the rising threat of insolvency for brokers). The contraction of credit forced more and more securities houses into liquidation. On October 3 the respected firm of E.W. Clark, Dodge, and Company failed (in which Jay Cooke was a partner). While discount rates rose and banks contracted, still there was no run. On October 10, however, the surprised New York market saw several railroad companies and the securities firm Corning and Company fail. Corning alone owed several million dollars to the city banks at the time of its failure. Anticipating panic, the Clearing House passed a resolution on October 12 pledging to maintain convertibility. But, like its earlier promise, this was not credible, and depositors' concerns were not allayed.

When New York City banks opened for business on October 13, an unprecedented run by depositors greeted them. Before agreeing to suspend, the banks paid out between $\$ 4$ million and $\$ 5$ million. Wall

${ }^{30}$ Cook, “Annual Report," p. 113.

${ }^{31}$ Thompson's, 1857, various issues. 
Street literally was filled with depositors hurrying to withdraw their funds. "The banks went down before a storm they could not postpone or resist." ${ }^{32}$ Between October 1 and October 13 deposits had fallen by $\$ 10$ million. Roughly half of the specie held by city banks on October 10 was paid out on October 13.

\section{TRANSMISSION TO OTHER STATES}

Suspension of convertibility in New York City was followed by suspension in the rest of New York state and most parts of the country. Many banks in other regional centers relied on New York, either directly or indirectly, as a reserve center. The suspension of convertibility in New York City, along with that of other northeastern financial centers, effectively reduced banks' reserve holdings. In Ohio, for example, this reduced reserves by half. ${ }^{33}$

Furthermore, the scramble for specie by suspended banks in Philadelphia, Baltimore, and New York City threatened runs on banks that remained open in the rest of the country. Bankers and local businessmen feared their banks would be run to provide specie for other locales. Often suspension of convertibility came at the behest of merchants who organized citizens' meetings to demand bank suspension. Such influential meetings occurred in New York, Tennessee, Georgia, and Virginia. ${ }^{34}$

In Virginia suspension came in two waves, and in both cases it was defensive. After the suspension of Philadelphia banks on September 26, banks in the western part of the state, which had the strongest financial ties with Pennsylvania banks, suspended. The Bank of the Valley, Wheeling, suspended on September 28 with the encouragement of the city's citizens, who feared withdrawals by Pennsylvanians. ${ }^{35}$ Banks in eastern Virginia did not suspend at that time. The out-of-state interbank holdings of Richmond and Norfolk banks, like those of other southern coastal city banks, were in New York. These banks and their counterparts in Augusta, Savannah, and Charleston continued to maintain convertibility until suspension in New York. ${ }^{36}$

In Georgia general bank suspension occurred immediately after that of New York and Charleston, and the motivation was described explicitly as a defensive response to actual and potential pressures from the North. ${ }^{37}$ Georgia's coastal cities' banks maintained large interbank

${ }^{32}$ Cook, "Annual Report," p. 115.

${ }^{33}$ The ratio of specie to specie plus interstate deposits was 0.53 on average for Ohio. See Calomiris, "Microeconomic Data."

${ }^{34}$ Ecke, "Fiscal Aspects," pp. 80-85, 92-94, 119.

${ }^{35}$ Ibid., p. 81.

${ }^{36}$ Ibid., pp. 82, 118-20. In anticipation of New York's suspension, some banks suspended as early as Oct. 12.

${ }^{37}$ Huston, in The Panic of 1857 , pp. 22-23, cited articles that explained suspension as a defensive action from the Richmond Enquirer on Oct. 16, and the Mobile Daily Reporter on Oct. 17. 
balances with the banks of Charleston, who in turn had large New York balances. Once the banks of Savannah and Augusta had followed Charleston's lead, the rest of the Georgia banks followed, again at the behest of their citizenries. ${ }^{38}$

Only two banks in Alabama suspended-the Central and Commercial banks-both entrants in 1857, while older banks opted to remain open and weather the storm. ${ }^{39}$ The lack of ties between Alabama and New York financial markets may have insulated Alabama from dependence on northern deposits and the risk of northern withdrawals. Similarly, New Orleans and Kentucky avoided suspension.

Bank suspension was not necessarily a sign of weakness. Maryland and Pennsylvania banks suspended with little effect on note discount rates in New York. Similarly, Charleston's bank notes circulated throughout the South during the suspension at par with specie. ${ }^{40}$ Indeed, the failure to suspend in response to persistent statewide bank runs can have far more serious consequences than a suspension. If to maintain convertibility banks call in loans from borrowers, they may cause customers to go bankrupt or to sell off merchandise at "fire sale" prices, which can result in bank losses as well. Suspension did not force banks to shut down; it allowed banks to choose which deposits and notes to redeem and permitted them to accumulate reserves gradually, without calling in loans en masse. Suspension also allowed banks to allocate reserves among themselves to the best use. ${ }^{41}$

In some states the authorities took a dim view of suspension. Joseph Brown, Georgia's antibank governor, attempted to enforce loss-ofcharter penalties on suspending banks. But in Georgia, as elsewhere, the voices of reason prevailed. The legislature understood the futility of penalizing Georgia banks, the victims of a financial crisis imported from the North. It permitted a one-year suspension without penalty over the governor's veto. ${ }^{42}$

In Virginia distaste for suspension led the state legislature to enact a law in 1859 to insulate banks from future crises in the North. The ingenious law allowed banks to redeem their demandable obligations in the form of either specie or drafts on financial-center banks. In the event of a suspension in other states, the out-of-state deposits of Virginia

${ }^{38}$ Ibid., p. 119.

${ }^{39}$ We infer this from the inaugural address of Alabama's Governor Moore of Dec. 1, 1857, in which he raised the possibility that these two banks might be penalized for suspending convertibility. See U.S. House of Representatives, "Extract from Governor Moore's," p. 196; Schweikart, Banking in the American South; Feiner, "Financial Structures"; and Schweikart, "Alabama's Antebellum Banks," pp. 202-21.

${ }^{40}$ Ecke, "Fiscal Aspects," p. 120.

${ }^{41}$ On interbank transfers during the post-War of 1812 bank suspensions, see Temin, The Jacksonian Economy, pp. 45-47. Below we discuss other examples.

${ }^{42}$ Heath, Constructive Liberalism, pp. 183-230. 
banks were as good as specie for purposes of forestalling a run on their own banks. ${ }^{43}$

New York allowed suspension of convertibility, so long as suspension was due to a liquidity crisis, like the Panic of 1857. An Act of 1849 provided that "where a [suspended] bank is clearly solvent and its officers are acting in good faith, \&c, no receiver should be appointed." 44 The law clearly distinguishes individual fraudulent behavior (for which banks should be punished) from systemic crises for which individual banks are not to blame.

\section{RESPONDING TO CRISIS: THE IMPORTANCE OF COORDINATION}

An exhaustive summary of each state's response to the panic is beyond our scope. We focus on a few states to illustrate the importance of banking-system coordination in limiting liability depletion and bank failures during the crisis. ${ }^{45}$ New York City's Clearing House, coinsuring statewide coalitions of banks in Indiana and Ohio, and southern statewide branch-banking system provide examples of relatively successful responses to the panic and stand in contrast to other systems of many unit banks which were unable to coordinate as effectively, including free banks in Indiana and Tennessee and interior New York banks.

\section{New York}

Recovery from the panic was rapid in New York. By the end of 1858 , banks had more than regained their pre-panic asset levels. In 1859 asset growth was flat. Long-run effects include more conservative capital and reserve ratios. From February 1856 to February 1860 banks increased their capital-asset ratios, from 0.33 to 0.40 for six cities outside Manhattan, and from 0.37 to 0.41 outside cities. Urban banks outside of Manhattan also showed an increase in interbank net deposits (from -1 percent of assets to 4 percent of assets). Conversely, banks in Manhattan decreased interbank deposits but kept total reserve ratios (specie plus net interbank deposits divided by assets) constant by raising specie from 5 to 8 percent of assets.

The Clearing House coordinated the behavior of its members during and after the panic, hastened resumption, and minimized the costs of the crisis. On November 7 the Clearing House banks resolved to require country banks to resume convertibility at $1 / 4$ percent, beginning November 20 , while the city banks agreed not to request immediate redemption of all interior bank currency. City banks held sealed

\footnotetext{
43 “'Law of Virginia in Relation to Banks," Hunt's Merchants' Magazine, 41 (1859), p. 596.

${ }^{44}$ Hunt's Merchants' Magazine, 37 (1857), p. 601.

${ }^{45}$ All balance sheet and bank failure data reported below are from Calomiris, "Microeconomic Data.",
} 
packages of interior bank currency totaling $\$ 7$ million, to be redeemed at 20 percent per month, with 6 percent interest payable on the balances held in the interim. This increased bank reserves beyond available specie and made withdrawals from interior banks more orderly and predictable. The plan also sought to satisfy city banks' depositors that city reserve depletion would be reversed. ${ }^{46}$

The Clearing House banks set December 11 as the date for resumption for themselves. By acting together they emphasized the collective nature of the problem and their resolve to meet the challenge as a group. Discount rates on interior banks' notes fully rebounded by late November (Table 4).

Although the Clearing House banks were instrumental in the recovery of the banking system, one might fault them for postponing suspension in the face of massive mercantile failures. Had they suspended in mid-September or even early October, they might have been able to extend the necessary loans to keep the securities market afloat. Focusing on their banks' reputations, rather than the health of the markets as a whole, the bankers chose the path of tight credit, falling prices, and commercial failures.

Of the 285 banks in New York in operation in September 1857, 19 failed during the panic. ${ }^{47}$ Of the three failed banks located in New York City, the Mechanics Banking Association soon reopened, while the other two-the Bowery Bank and the Island City Bank-suffered respective discounts of 0 and 0.25 percent on their notes and ultimately redeemed their circulation at par. ${ }^{48}$ Failed banks outside Manhattan saw higher losses. Interestingly, Safety Fund banks in the periphery were more likely to fail than interior free banks, and the degree of losses conditional on their failing was higher. Only 6 of the 221 interior free banks in existence in September 1856 failed, while 3 of the 41 interior Safety Fund banks failed. Discounts on failed free banks averaged 0.75 percent, while discounts on the three failed Safety Fund banks averaged 37 percent. Individual banks-those with bond-backed circulation and unlimited liability to the banker-were the most likely to fail ( 8 out of 35 ), but average note discount rates ( 2.25 percent) on failed individual banks were low compared to Safety Fund banks.

What is puzzling about these relatively large noteholders' losses for the Safety Fund banks is that their note discounts in New York, Boston, Baltimore, and Philadelphia prior to the panic were identical (indeed, a little lower on average) to those of free banks and individual banks. How

\footnotetext{
${ }^{46}$ Cook, "Annual Report," p. 119.

47 Another free bank, the Powell Bank in Newburgh, is listed as "closed" during this period. Its notes were discounted 1 percent and no receiver or deadline for redemption appears in the note reporters. Listings of failed banks from other sources-like New York's Sound Currency, Feb. 1, 1895 , p. 303-do not include the Powell Bank in their list.

${ }^{48}$ Sound Currency, Feb. 1, 1895, p. 303.
} 
can one reconcile the similar evaluation of risk ex ante with the difference in losses ex post? A possible answer is the novelty of the 1857 crisis. As New York's Banking Superintendent pointed out, it was the first banking crisis in the United States of its kind. Earlier financial crises could be traced to the impact of war (as during and after the War of 1812) or to the policies of the Bank of England (which had prompted the Panic of 1837). ${ }^{49}$ No one had anticipated the course that the panic took. In particular, no one could have anticipated that the New York court would allow interior banks to withdraw all of their bonds on deposit at the banking department in order to redeem their notes. In fact, this was probably illegal, and the request to do so had been denied by the Superintendent prior to the ruling of the court. That ruling allowed free banks to meet the redemption requirement with relative ease, but it did not help the Safety Fund banks, since they did not have bonds on deposit at the banking department. Thus the Safety Fund banks were faced with a more costly convertibility requirement ex post, though neither the origins of the crisis nor the special dispensation for free banks was anticipated ex ante. This may explain the similarity in ex ante risk evaluation of free and Safety Fund banks, even though free banks performed better during the crisis.

\section{Ohio}

Ohio provides an interesting example of a banking system that performed well despite the shocks that buffeted western markets. In Ohio from 1856 to 1860 capital-asset ratios rose (from 0.25 to 0.28 ) for both insured and uninsured banks, and assets did not fully rebound in the two years after the panic. This likely reflects deterioration in Ohio's "fundamentals," rather than the failure of its banks to recover from the crisis. Ohio produced a quarter of the total wheat output of the United States during this period. The Warren-Pearson price index for farm products rose steadily from 59 in 1848 to 95 in 1857 , only to fall to the mid-70s in 1858 and remain there for the rest of the decade. At the same time, the price index for all commodities rose from 82 to 111 from 1848 to 1857 , and then declined to the mid-90s for 1858-1860. Thus relative farm prices appreciated 19 percent from 1848 to 1857 , declined 4.5 percent in 1858 , and remained flat until the $1860 \mathrm{~s}^{50}$

Ohio avoided a general suspension through the cooperation of the network of mutually insured banks, which their (self-)regulator, the Board of Control, orchestrated. Ohio banks were especially vulnerable in 1857 because many of them had substantial eastern deposits on account with Ohio Life. Also, the law bound each member of the insured system to redeem the notes of all member banks, making each

${ }^{49}$ Cook, “Annual Report,", pp. 105-17.

${ }^{50}$ U.S. Bureau of the Census, Historical Statistics, part 1, pp. 218-20. 
more accessible to withdrawal of specie by local residents. But coinsurance, along with actions by the Board of Control, compensated for these potential problems. First, the Board of Control acted quickly to insulate the banks from Ohio Life's failure. It transferred assets of the failed bank directly to its depositor banks to secure their deposits, effectively subordinating the debts of individual depositors and other creditors of Ohio Life to those of the Ohio banks. The board liquidated some of these assets to help keep banks afloat during the crisis. ${ }^{51}$

Second, the board established a system of mutual liquidity insurance among the banks. Just three days after the failure of Ohio Life, the board determined it could minimize the impact of the failure by requiring banks to help each other during the crisis (rather than simply rely on ex post coinsurance). ${ }^{52}$ On August 29 the first letter from the secretary instructed the Commercial Branch in Cleveland to "render aid" in the amount of $\$ 15,000$ to the Merchant's Branch of Cleveland. Over the next two months, four insured banks received $\$ 56,000$ in assistance. These were interest-bearing loans, backed by collateral of time notes or paper currency. The sweeping powers of the Board of Control gave it the flexibility to react quickly to the crisis and with unquestionable authority. This timely action allowed all of the insured banks to maintain full convertibility throughout the crisis. They had a rapid recovery, and by the end of 1858 their average level of assets had nearly regained pre-panic levels.

The beneficial effects of the Board of Control's policy went beyond the limits of the insured system. By establishing the credibility of the insured banks, the board avoided panic by the uninsured banks and their depositors, allowing other banks to draw on the insured banks to keep themselves afloat, and kept their holdings of insured banks' notes as good as gold for purposes of maintaining their own convertibility. The net interbank balance for all Ohio banks rose from November 1856 to February 1858, but this mainly reflected net loans from insured banks. Other banks increased their net interbank positions by $\$ 77,000$ as a group, while the insured banks increased their net interbank balance from $\$ 368,000$ in November 1856 to $\$ 670,000$ in February 1858 . This increase implies that loans to uninsured banks and repayments on deposits due to other banks were an important indirect benefit of cooperation among insured banks.

Only 1 of the 54 Ohio banks-the Seneca County Bank, an uninsured "independent bank of moderate size"-failed in Ohio during the crisis. Judging from note discount rates the market also perceived the Sandusky City Bank as vulnerable, but the bank recovered and by 1859 its notes traded at the same discount in New York as all other solvent

${ }^{51}$ Golembe and Warburton, Insurance of Bank Obligations, chap. 6, p. 30.

${ }^{52}$ Letterbooks of the Board of Control, MSS, Ohio State Museum, Columbus, Aug. 27, 1857, taken from Golembe and Warburton, Insurance of Bank Obligations, chap. 6, p. 29. 
banks. Notes of the Seneca County Bank were discounted 80 percent. ${ }^{53}$ This high a rate of loss seems inconceivable given the 100 percent bond backing required of independent and free banks for their note issues. ${ }^{54}$ It appears, however, that independent banks, unlike free banks, may not have been required to deposit their bonds with the state auditor. ${ }^{55}$ Violation of the bond reserve requirement possibly explains this high rate of noteholder loss.

The success of Ohio banks in meeting the liquidity crisis appears in sharp contrast to some of their neighbors in Indiana. Of Indiana's 32 free banks in operation prior to the panic, 14 failed during the panic. The difference in the propensity to fail in the two states in 1857 cannot be attributed to a steeper decline in bond prices held by Indiana banks. Indiana's 5 percent bonds fell 14.6 percent from peak to trough during the panic, while Ohio's 6 percent bonds fell 16.7 percent from peak to trough. Both recovered to their pre-panic levels by the end of the year. ${ }^{56}$

An explanation for the different propensities to fail may be found in the relative lack of a coordination mechanism in Indiana. The insured banks in Indiana, like those in Ohio, maintained specie convertibility throughout the crisis. But unlike the insured banks in Ohio, Indiana's were in a state of flux throughout the 1850 s and in no position to aid the free banks or to coordinate their behavior. The charters of the first system of Indiana insured banks (the "branches" of the State Bank of Indiana) expired at the beginning of 1857. In 1854 an effort to renew the charters failed. A second political battle was joined after the regional crisis of 1854-1855 to charter a new system of insured banks (the "branches" of the Bank of the State of Indiana). Many free bank failures in 1854-1855 made the insured system seem attractive by comparison, and this time the forces in favor of insured banking succeeded in securing a new set of charters. However, the Panic of 1857 came too soon for these banks to have developed ties to the free banks. The old insured banks had closed, and the new insured banking network had only been operating for a few months. Interestingly, the free banks responded to the crisis of 1854-1855 with their own plans for coordination. In June 1857 the free banks met to discuss forming a clearing house on New York's model. Unfortunately the panic came before they were able to do so.

Evidence from note discount rates supports our interpretation of the difference between Indiana and Ohio. Philadelphia data, for which a

\footnotetext{
${ }^{53}$ Thompson's does not quote New York prices for this bank and refers to its notes as "unsalable." The 80 percent discount is a Philadelphia price taken from Van Court's, Dec. 1858.

${ }^{54}$ Ohio and U.S. bonds, which were required as backing for notes, fell no more than 16.7 percent before recovering their value.

${ }^{55}$ On their balance sheets independent banks reported "bonds of U.S. and State of Ohio," while free banks reported "state stocks deposited with Auditor."

${ }^{56}$ Thompson's, 1857, various issues.
} 
consistent series is available for 1857-1858 from Van Court's Counterfeit Detector and Bank Note List, suggest that during the panic the notes of Ohio banks of all types traded at the same rate of discount (which varied over time from 1 to 10 percent in the Philadelphia market) with few exceptions. For Indiana the discount rates on all free banks' notes rose from 2 percent in September to 10 percent in October. By February 1858 , however, discounts on Indiana free banks' notes varied within the range of 5 to 30 percent, with a mode of 20 percent. At the same time, the discounts on the notes of the insured system had risen from 1.25 percent in September to 5 percent in October, and had fallen to 3 percent by December and 2 percent by February. These data indicate separate pricing of bank risk in Indiana, and common pricing of risk in Ohio, across the different charter types. This supports the view of Ohio's system as interdependent or coordinated, and Indiana's free banks as a system of "every bank for itself."

\section{The Branching South}

The antebellum South had no clearing houses. Six northern states experimented with bank coinsurance during this period, but no southern state did. While the South lacked these formal devices, it achieved coordination through informal agreements among smaller numbers of banks, made possible by branch banking, which was unique to the South.

Data for Virginia show banks weathered the storm well. While all banks contracted from January 1857 to January 1858 , the six banks with branches showed a rise in the ratios of deposits, and loans, to assets at a time when other banks' deposit and loan shares fell. Loan shares of branching banks rose from 0.72 to 0.74 , while the average for the state fell from 0.49 to 0.46 . By January 1859 banks had more than recovered from the asset depletion of the panic. Bank growth did not continue in 1859. Virginia, like Ohio and New York, increasingly depended on the fortunes of the grain market and suffered by its decline. For example, the Bank of Rockingham-a unit bank located in Harrisonburg-saw its loans and deposits fall by roughly a third from January 1857 to January 1860. Two of Virginia's 19 banks (operating 40 branches) failed during the panic: the Bank of Kanawha (a unit bank granted a special charter in 1839) and the Trans-Alleghany free bank. The former soon reorganized, and its notes traded in New York at 95 cents on the dollar. The latter bank's notes fell to 50 cents on the dollar.

Data on Georgia banks tell a similar story. By the end of 1858 , notes and deposits had exceeded their 1857 levels, though, as in other states, growth was flat afterward. Four out of 19 banks (operating 15 branches and agencies) closed during the panic. All four failures were unit banks. Two were new entrants, the other two were owned by George Smith and his partners to provide circulation in Illinois (and avoid Illinois' costly 
regulations): the Atlanta Bank and the Interior Bank of Griffin-both chartered in 1854 without agencies or branches. These two banks, like many of Smith's other operations, most likely closed in anticipation of his retirement to Scotland in $1857 .{ }^{57}$ Notes of these two banks were discounted 3 percent after their closing. Thus of the four unit banks that closed during and after the panic, two were new entrants into banking, and two were retired.

Data for other southern states show a remarkable degree of success in coping with the panic. In Alabama, the Carolinas, Louisiana, Kentucky, and Missouri no banks failed. A branch was converted into a separate bank in North Carolina; Kentucky added one bank and six branches; four banks entered in Louisiana; two in Alabama; and six banks and nine branches in Missouri.

Tennessee, the southern state that relied most on free banking in the $1850 \mathrm{~s}$, suffered seven bank failures and large noteholder losses, as indicated by discounts of between 10 and 75 percent on its failed banks' notes in New York, compared to discounts of 1 percent on survivors' notes. Of the banks that failed, four were free banks and the other three were individually chartered unit banks. By 1860 only 2 of the 21 banks chartered under the free banking law had avoided liquidation. In this light, the repeal of the free banking law in Tennessee in 1858 is understandable. Relative to its neighbors without free banking, Tennessee had fared poorly during the panic, with free banks performing worst.

In part, the favorable performance of the South during the panic reflects cooperation between banks and merchants who often helped to coordinate bank suspensions. Cooperation among banks was important as well. On October 20,1857, banks in Charleston-a southern money center-agreed to receive each other's notes and the notes of other South Carolina banks and of Augusta and Savannah banks at par, effectively expanding the supply of reserves by making notes as good as gold for interbank transactions.

In Alabama a small number of mainly urban banks cooperated during the crisis. Total deposits due from banks rose for the four banks in existence from 1857 onward, from $\$ 665,000$ to $\$ 1.03$ million from the beginning of 1857 to the beginning of 1858 , while total deposits due to these banks fell from $\$ 703,000$ to $\$ 564,000$. This rise in net deposits due from banks may reflect the difficulty of obtaining funds from some out-of-state banks. The small percentage fall in deposits due to other banks (relative to public deposits) reflects cooperative behavior among Alabama's banks. Large banks (the Bank of Mobile and the Southern Bank of Alabama) doubled their balances due from other banks and reduced balances due to other banks by over $\$ 400,000$. The Bank of Montgomery began 1857 with a net balance of interbank claims of

\footnotetext{
${ }^{57}$ Huston, Financing an Empire, vol. 1, pp. 113-14.
} 
$-\$ 100,000$ and ended it with a net balance of $-\$ 386,000$. Similarly, in Georgia changes in interbank balances also indicate cooperative behavior. The three largest banks (the Georgia Railroad and Banking Co., the Central Railroad and Banking Co., and the Bank of the State of Georgia) increased their interbank balances by a total of $\$ 1.14$ million, mainly by paying debts due to other banks.

An analysis of aggregate interbank balances of southern states in 1857 and 1858 suggests interbank transfers across, as well as within, state lines. In 1857 Virginia and Louisiana banks called in large amounts of deposits and borrowed heavily from other southern states in response to the crisis. New Orleans banks began 1857 with a positive net interbank balance of $\$ 5.4$ million. By the beginning of 1858 the banks had reduced their net interbank balance to $\$ 2.7$ million. Virginia's aggregate interbank balance fell from $\$ 1.7$ million to $\$ 1.1$ million over the same time. These negative changes in net interbank balances were offset by opposite changes in Alabama, Georgia, South Carolina, and Tennessee. From September 1857 to March 1858, South Carolina reduced its out-of-state interbank balance by roughly $\$ 500,000$. Georgia went from a $\$ 300,000$ net debt in the beginning of 1857 to a $\$ 400,000$ net credit by October of 1857, though nonreporting banks make it difficult to say whether this reflected changes across state lines. Tennessee's change was roughly $\$ 1$ million, and Alabama's $\$ 600,000$. This indirect evidence indicates a reallocation of bank balances across state lines, possibly to support troubled banks. Suspension did not close the banking system; rather, it gave banks flexibility to allocate reserves according to need.

Cooperative behavior among southern banks goes back at least as far as the Panic of 1837, as Thomas Govan discussed in his study of Georgia. He found that early calls for suspension came from merchants, and that such local concerns translated into state- and regional-level banking policy by meetings and explicit arrangements among bankers. ${ }^{58}$

The reliance on large branching banks in the South facilitated ad hoc cooperative planning. Contemporaries noted that the small number of large banks made it easier to cooperate. The banks of New Orleans and Kentucky and the insured banks in Indiana maintained convertibility during the Panic of 1857, and as Bray Hammond noted, New York state banks could not because they had many more players to coordinate. ${ }^{59}$ Also, in banking systems with many geographically isolated banks, the costs of monitoring other coalition members' actions to enforce selfregulation is higher, and the benefits of monitoring are spread too thinly among many banks to permit incentive-compatible cooperation. In regional negotiations, like those described by Govan, the large branching banks could speak confidently on behalf of all banks in their state

${ }^{58}$ Govan, "The Banking and Credit System," pp. 15-19.

${ }^{59}$ Hammond, Banks and Politics, p. 712. Also see Gibbons, The Banks of New York, p. 357; Dunbar, Economic Essays, p. 283; and McCulloch, Men and Measures, pp. 132-35. 
because they had the ability to enforce cooperative behavior. ${ }^{60}$ In this light, the coordination of northern banks through formal institutions like city clearing houses and deposit insurance systems can be viewed as necessities in the North, which followed from its reliance on unit banking. ${ }^{61}$ In addition to the benefits of coordination, branching also brought stability by enhancing opportunities for diversification. As the experiences of New York, Ohio, Georgia, Tennessee, and Virginia demonstrate, small unit banks were most vulnerable.

The importance of coordination in limiting bank suspension and failure is reflected in comparisons within and across states during the panic. Ohio's banks, Indiana's coinsuring banks, and southern branch banks in the Carolinas, Georgia, Kentucky, Tennessee, and Virginia outperformed unit banks-in particular Indiana's and Tennessee's unit free banks. Furthermore, as Table 2 shows, Ohio, Georgia, the Carolinas, and Virginia suffered commercial distress during the panic equal to or in excess of that of Tennessee, but with far fewer bank failures. Our analysis of antebellum bank performance contrasts with that of Arthur Rolnick and Warren Weber, who viewed the causes of bank failures as exogenously determined by declines in asset values. ${ }^{62} \mathrm{We}$ would add to their analysis the potential for banking systems to limit the declines in asset values and to reduce the effects of such declines through cooperation.

${ }^{60}$ Govan, "The Banking and Credit System," pp. 19, 194.

${ }^{61}$ See Calomiris, "Deposit Insurance," and "Is Deposit Insurance Necessary?"; and White, "Political Economy.",

${ }^{62}$ Rolnick and Weber, "The Causes of Free Bank Failures."

\section{REFERENCES}

Boyle, James E., Chicago Wheat Prices for Eighty-One Years (Ithaca, 1922).

Calomiris, Charles W., "Deposit Insurance: Lessons from the Record," Economic Perspectives, Federal Reserve Bank of Chicago, 13 (May/June 1989), pp. 10-30.

Calomiris, Charles W., "Is Deposit Insurance Necessary? A Historical Perspective," this Journal, 50 (June 1990), pp. 283-95.

Calomiris, Charles W., "Microeconomic Data and Institutional Constraints of Antebellum Banking: Sources and Methods" (Mimeograph, Northwestern University, Dec. 1990).

Calomiris, Charles W., and Gary Gorton, "The Origins of Banking Panics: Models, Facts, and Bank Regulation," in R. Glenn Hubbard, ed., Financial Markets and Financial Crises (Chicago, 1991).

Cashin, Joan, A Family Venture: Men and Women on the Southern Frontier (Oxford, 1991).

Cincinnati Enquirer (various issues).

Cook, James, "Annual Report of the Superintendent of the Banking Department of the 
State of New York," in U.S. House of Representatives, Executive Document No. 77 (Washington, DC, 1858).

Dunbar, Charles F., Economic Essays (New York, 1904).

Ecke, Melvin, "Fiscal Aspects of the Panic of 1857" (Ph.D. diss., Princeton University, 1951).

Evans, D. Morier, The History of the Commercial Crisis, 1857-1858 and the Stock Exchange Panic of 1859 (London, 1859).

Fehrenbacher, Don E., Slavery, Law and Politics: the Dred Scott Case in Historical Perspective (Oxford, 1981).

Feiner, Susan F., "The Financial Structures and Banking Institutions of the Antebellum South: 1811-1832" (Ph.D. diss., University of Massachusetts, 1981).

Fishlow, Albert, American Railroads and the Transformation of the Ante-Bellum Economy (Cambridge, MA, 1965).

Gates, Paul W., "Land and Credit Problems in Underdeveloped Kansas," Kansas Historical Quarterly, 31 (Spring 1965).

Gibbons, James S., The Banks of New York, Their Dealers, the Clearing House, and the Panic of 1857 (New York, 1859).

Golembe, Carter H., and Clark Warburton, Insurance of Bank Obligations in Six States During the Period 1829-1866, Federal Deposit Insurance Corporation (Washington, DC, 1958).

Govan, Thomas, "The Banking and Credit System in Georgia" (Ph.D. diss., Vanderbilt University, 1936).

Hammond, Bray, Banks and Politics in America from the Revolution to the Civil War (Princeton, 1957).

Haeger, John D., The Investment Frontier: New York Businessmen and the Economic Development of the Old Northwest (Albany, 1981).

Hawtrey, R. G., A Century of Bank Rate (London, 1938).

Heath, Milton, Constructive Liberalism: The Role of the State in Economic Development in Georgia to 1860 (Cambridge, MA, 1954).

Hunt's Merchants' Magazine (New York, various issues).

Huston, Francis M., Financing an Empire: History of Banking in Illinois (Chicago, 1926).

$\rightarrow$ Huston, James L., "Western Grains and the Panic of 1857," Agricultural History, 57 (1983), pp. 14-32.

Huston, James L., The Panic of 1857 and the Coming of the Civil War (Baton Rouge, 1987).

Jevons, W. Stanley, Investigations in Currency and Finance (London, 1884).

McCulloch, Hugh, Men and Measures of Half a Century (New York, 1889).

Nevins, Allen, The Ordeal of the Union, the Emergence of Lincoln, Douglas, Buchanan, and Party Chaos, 1857-1859 (New York, 1950).

Potter, David, The Impending Crisis 1848-1861, edited by Don E. Fehrenbacher (New York, 1989).

Ransom, Roger L., Conflict and Compromise: The Political Economy of Slavery, Emancipation, and the American Civil War (New York, 1989).

Rolnick, Arthur, and Warren Weber, "The Causes of Free Bank Failures: A Detailed Examination," Journal of Monetary Economics, 14 (Nov. 1984), pp. 267-91.

Salsbury, Stephen, The State, the Investor, and the Railroad: The Boston \& Albany, 1825-1867 (Cambridge, MA, 1967).

Schweikart, Larry, "Alabama's Antebellum Banks: New Evidence, New Interpretations," Alabama Review, 38 (July 1985).

Schweikart, Larry, Banking in the American South from the Age of Jackson to Reconstruction (Baton Rouge, 1987).

Sound Currency (New York, various issues). 
Speigelman, Mortimer, "The Failure of the Ohio Life Insurance and Trust Company, 1857," Ohio State Archaeological and Historical Quarterly, 57 (1948), pp. 247-65.

Statistical Abstract for the United Kingdom: Accounts and Papers, 71 (1867).

Temin, Peter, The Jacksonian Economy (New York, 1969).

Temin, Peter, "The Panic of 1857," Intermountain Review, 6 (Spring 1975), pp. 1-12. Thompson's Bank Note and Commercial Reporter (New York, various issues).

U.S. Bureau of the Census, Historical Statistics of the United States from Colonial Times to 1970 (Bicentennial Edn., Washington, DC, 1975).

U.S. House of Representatives, "Extract from Governor Moore's Inaugural Address to the Legislature of Alabama," Executive Document No. 77 (Washington, DC, 1858).

U.S. House of Representatives, "Synopsis of the Report of the Trustee of the Ohio Life Insurance and Trust Company," Executive Document No. 107 (Washington, DC, Feb. 6, 1860).

Van Court's Counterfeit Detector and Bank Note List (Philadelphia, various issues).

Van Vleck, George W., The Panic of 1857: An Analytic Study (New York, 1943).

White, Eugene Nelson, "The Political Economy of Banking Regulation, 1864-1933," this Journal, 42 (Mar. 1982), pp. 33-40.

Wright, Gavin, The Political Economy of the Cotton South: Households, Markets, and Wealth in the Nineteenth Century (New York, 1978). 